\title{
ChARACTERIZATION AND ANTIMICROBIAL ANALYSIS OF FLAVONOIDS IN VERNONIA AMYGDALINA : A COMMON CHEWING STICK IN SOUTH-WESTERN NigERIA
}

\author{
Julius Oloke ${ }^{1}$, Kehinde Odelade ${ }^{1 *}$ and Oluwole Oladeji ${ }^{2}$ \\ ${ }^{1}$ Department of Pure and Applied Biology; ${ }^{2}$ Department of Pure and Applied Chemistry, Faculty of \\ Pure and Applied Sciences, Ladoke Akintola University of Technology, Ogbomoso, Oyo State, Nigeria \\ *E-mail: kennybramm@gmail.com \\ Tel.: +2348067624977
}

Received: Nov 14, 2017 / Revised: Dec 15, 2017 / Accepted: Dec 16, 2017

In South-Western Nigeria, local people chew the stems of the plant Vernonia amygdalina (chewingstick) to inhibit the negative effects of oral microbial activity. The use of chewing-stick is increasing; this could be due to financial constraints and/or belief in the cleansing ability of chewing stick. To investigate the bioactive compounds of Vernonia amygdalina, the phytochemical and antimicrobial screening was carried out using agar disc diffusion method. The highest zone of inhibition of $\mathbf{2 2 . 5}$ $\mathrm{mm}$ was recorded for $P$. aeruginosa and lowest zone of inhibition of $10.5 \mathrm{~mm}$ for $A$. flavus. The phytochemical analysis identified important secondary metabolites such as anthraquinones, flavonoids, steroids and saponins. The presence of the phytochemicals (flavonoids) could be responsible for the observed antifungal and antibacterial activities on the susceptible organisms studied.

Key words: Microbes, Chewing stick, Vernonia amygdalina, Flavonoids, Antimicrobial activities.

\section{INTRODUCTION}

The use of herbal medicine for the treatment of diseases caused by bacteria and fungi gave rise to the development of natural antibiotics (Akinyemi, 2000). Plants are important sources of medicines and play a key role in world health. Almost all cultures from ancient times to today have used plants as medicine. Medicinal plants are important to the global economy (Adekunle and Odukoya, 2006), as approximately $85 \%$ of traditional medicine preparations involve the use of plants or plant extracts (Vieira and Skorupa, 1993).

The use of plant-based drugs world-wide is increasing. Through recent researches on herbal plants, there have been great developments in the pharmacological evaluation of various plants used in traditional systems of medicine (Shrestha et al 2016; Gajendiran et al 2016;
Agarwal et al 2015; Avula et al 2015; Srividya et al 2012; Dahiya, 2008; 2007; Dahiya and Kumar, 2008). Herbal plant products are emerging all over the world due to the belief that many herbal medicines are free from health and environmental effects. The widespread fear of the side-effects of synthetic drugs often accompanies their single or multiple health benefits (Al Sadhan and Almas, 1999).

In South-Western Nigeria, local people chew the stems of the plant Vernonia amygdalina (chewing-stick) (Figure 1) for oral hygiene.

Recent interest in chewing-sticks and their extracts has focused on their effects on organisms that are involved in oral infections. Africans who use chewing-sticks have fewer carious lesions than those who use toothbrushes and chewing-stick usage has been encouraged by World Health Organization (Ndukwe et al 2005). 


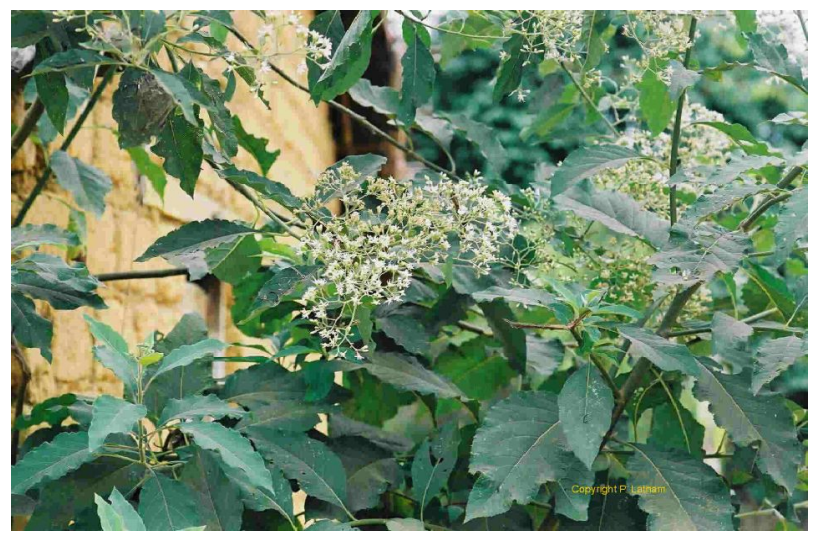

Fig. 1. Image of plant V. amygdalina

In some countries, however, the National Health Agencies have restricted and discouraged the people from the use of chewing-sticks from plants because of a lack of studies to analyze and characterize the chemical composition of the plant raw material and ensure the effectiveness and safety (Chopra et al 1956). Therefore, there is a need to examine the bioactive components present in Vernonia amygdalina.

\section{MATERIALS AND METHODS Chemicals}

Chemicals were from Sigma unless otherwise stated. All chemicals and solvents used were of analytical grade.

\section{Sample collection and preparation}

The plant materials were collected from a farm in Ogbomoso and identified by the herbarium unit of the Department of Pure and Applied Biology, LAUTECH, Ogbomoso Oyo State, Nigeria. The samples were air-dried for 25 days, pulverized and sieved through a mesh size of 20 $\mathrm{mm}$.

\section{Extraction}

Soxhlet apparatus was used for the extraction according to a developed method (Adelowo and Oladeji, 2016) with a little modification in the solvents ethanol and methanol.

\section{Concentration}

The extracts were concentrated using a Rotary Evaporator. Three concentrated extracts were obtained using ethanol, ethyl acetate and chloroform as solvents.

\section{Clean up}

The clean-up method was carried out based on the method reported in the literature (Adelowo and Oladeji, 2016).

\section{Thin-layer chromatography analysis of phenolic compounds}

Thin-layer chromatography was performed using pre-coated silica plates. The solvent system used was petroleum ether : ethanol : acetone (5:3:1 vol: $18 \mathrm{ml})$ as the mobile phase.

\section{FT-IR spectroscopic analysis of phenolic compounds}

The spectrophotometric analysis was carried out according to the reported method in the literature (Adelowo and Oladeji, 2016).

\section{Phytochemical screening}

Qualitative screening of the phytochemical components of the chewing sticks was carried out to detect the presence of alkaloids, saponins, tannins, flavonoids, anthraquinone, steroids, terpernoids, reducing sugars and phlobatannins (Owoyale et al 2005).

\section{Screening for antimicrobial activity}

Preparation of solutions of the fractions

Stock solutions of extracts at $25 \mathrm{mg} / \mathrm{ml}$ were prepared by dissolving $0.05 \mu \mathrm{g}$ of each extract in $20 \mathrm{ml}$ of de-ionized water. Other concentrations of the extracts were prepared by serial dilution of the stock solution.

\section{Preparation of fungus and bacteria culture}

The fungi were cultured on Potato Dextrose Agar (PDA) and the bacteria on Nutrient Agar in accordance to the reported method (Owoyale et al 2005). The isolates were identified at the microbiological laboratory of the Department of Pure and Applied Biology, LAUTECH, Ogbomosho, Nigeria.

\section{Antifungal and antibacterial screening}

The antifungal activity of the fraction(s) was determined after incubating at $30^{\circ} \mathrm{C}$ for 3 days. The antibacterial activity of the fraction(s) was determined after incubating at $37^{\circ} \mathrm{C}$ for $24 \mathrm{~h}$.

Antibiotic susceptibility test on the collected bacteria and fungi

Streptomycin and Gentamicin were used as positive controls for gram-negative and grampositive bacteria respectively while Nystatin was used as positive control for the fungi tested.

\section{Statistical analysis}

The Statistical Package for Social Scientists (SPSS, version 19.0) and two way ANOVA test were used to determine the level of significance 
of the crude extracts at different concentrations.

\section{RESULTS AND DISCUSSION}

\section{Thin-layer chromatographic analysis of} flavonoids

The retardation factors of $V$. amygdalina were analyzed on a pre-coated silica gel plate. The $R_{f}$ values obtained were compared with the standard (Table 1). The qualitative analyses of the chloroform, ethyl acetate and ethanolic fractions of $V$. amygdalina stem were carried out using Quercetin as the standard for flavonoid content. The mean $R_{f}$ values show proximity to that of Quercetin which indicates the presence of some content of flavonoids. The detected spots exhibited light yellow appearance on silica gel plate, indicating the presence of flavonoids.

Table 1. The $\mathrm{R}_{\mathrm{f}}$ values and their mean values of the Vernonia amygdalina extracts spotted

\begin{tabular}{|c|c|c|}
\hline $\begin{array}{c}\text { Sample } \\
\text { spotted }\end{array}$ & $\mathbf{R}_{\mathbf{f}}$ values & $\begin{array}{c}\text { Mean } \mathbf{R}_{\mathbf{f}} \\
\text { values }\end{array}$ \\
\hline Chloroform & $0.68,0.71,0.74$ & 0.71 \\
\hline Quercetin & $0.64,0.67,0.72$ & 0.68 \\
\hline Ethanolic leaf & $0.64,0.72,0.75$ & 0.70 \\
\hline Ethyl acetate & $0.66,0.71,0.73$ & 0.70 \\
\hline
\end{tabular}

FT-IR spectroscopic analysis of flavonol in Vernonia amygdalina

The FT-IR spectrum of Vernonia amygdalina showing the important functional bands and peaks (Figure 2). Flavonol is one of the most important phytochemical compounds present in Vernonia amygdalina. Flavonols are known to possess a characteristic structure containing an aromatic ring cross-linked together (Adelowo and Oladeji, 2016). The $\mathrm{O}-\mathrm{H}$ bond indicated the presence of hydrogen bonding. The $\mathrm{O}-\mathrm{H}$ functional group of the flavonol absorbed at $3500 \mathrm{~cm}^{-1}$ which could be due to the mesomeric effect with the electron withdrawing group such as $\mathrm{C}=0$. The weak band of $2972.31 \mathrm{~cm}^{-1}$ and $2924.09 \mathrm{~cm}^{-1}$ indicated the presence of aryl C-H stretching of the flavonols aromatic ring. The sharp band at $1454.33 \mathrm{~cm}^{-1}$ indicated the presence of $\mathrm{C}-\mathrm{O}$ stretching of ketone on carbon one $\left(C_{1}\right)$ and the wave number of $1649.14 \mathrm{~cm}^{-1}$ confirmed the presence of a conjugated carbonyl group ( $\mathrm{C}=0$ stretch) of ester (Table 2 ).

\section{Phytochemical screening}

The important phytochemicals present in the ethanol, ethyl acetate and chloroform extracts of $V$. amygdalina are presented in Table 3. The preliminary phytochemical screening revealed the presence of anthraquinones, tannins, steroids, flavonoids, terpernoids, saponins and alkaloids.

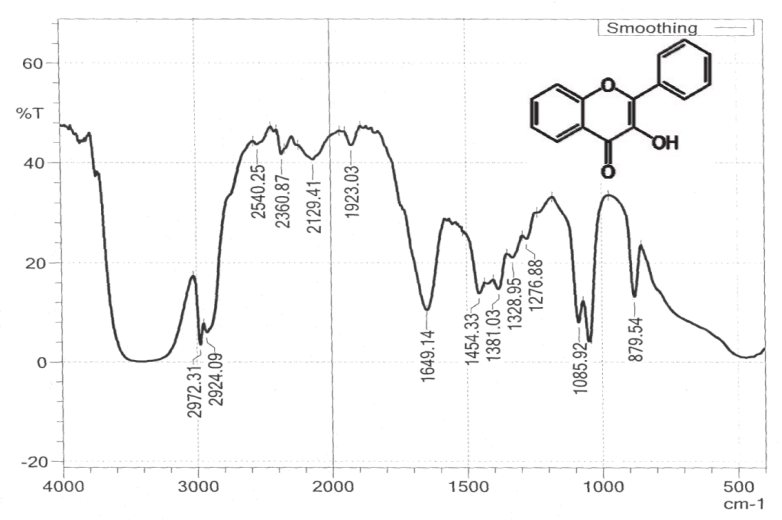

Fig. 2. FT-IR spectrum of Vernonia amygdalina

Table 2. The bands and the corresponding functional groups obtained from the spectrum

\begin{tabular}{|c|c|}
\hline Band (cm-1) & Functional group \\
\hline 3500.00 & O-H stretch \\
\hline 2972.31 & C-H stretch \\
\hline 2924.09 & C-H stretch \\
\hline 1923.03 & C=C stretch \\
\hline 1649.14 & C=O stretch \\
\hline 1454.33 & C-O stretch \\
\hline
\end{tabular}

Flavonoids and tannins have been reported to be antioxidants used to neutralize highly unstable and extremely reactive molecules like free radicals that attack the cells of human body (Karthishwaran et al 2010). The V. amygdalina contains a wide variety of secondary metabolites or compounds such as tannins terpernoids, alkaloids, flavonoids; that dictates the therapeutic potency of the plants (Sule et al 2010). The use of $V$. amygdalina stem for chewing helps inhibit mouth microbes; this may be due to the presence of these phytochemicals (Onwuliri, 2004).

\section{Antimicrobial activity of Vernonia amygdalina}

The ethanol extract showed high activity against all the test organisms with the exemption of $A$. Flavus. The highest zone of inhibition (ZOI) was observed at $\mathrm{C}_{1}(500 \mathrm{mg} / \mathrm{ml})$. The zone of inhibition of $10.5 \mathrm{~mm}$ at $500 \mathrm{mg} / \mathrm{ml}$ was observed in A. flavus. The zone of inhibition of $20.0 \mathrm{~mm}$ was observed at $500 \mathrm{mg} / \mathrm{ml}$ for ethyl acetate extract against $A$. niger and $9.5 \mathrm{~mm}$ at $500 \mathrm{mg} / \mathrm{ml}$ for $A$. flavus. The ZOI of $18.5 \mathrm{~mm}$ at $500 \mathrm{mg} / \mathrm{ml}$ was observed in P. aeruginosa and Klebsiella sp and the ZOI of $11.0 \mathrm{~mm}$ at 500 $\mathrm{mg} / \mathrm{ml}$ for A. flavus and Candida sp (Figure 3). 
Table 3. Phytochemical components of ethanol, ethyl acetate and chloroform extracts of $V$. amygdalina

\begin{tabular}{|c|c|c|c|}
\hline Active compound & Ethanol extract & Ethyl acetate extract & Chloroform extract \\
\hline Anthraquinone & + & - & - \\
\hline Tannins & + & - & - \\
\hline Phlobatannins & - & - & - \\
\hline Steroids & - & - & + \\
\hline Flavonoids & + & + & - \\
\hline Terpernoids & + & - & + \\
\hline Saponins & + & + & - \\
\hline Alkaloids & + & + & \\
\hline
\end{tabular}

Keys: + = present, - = absent

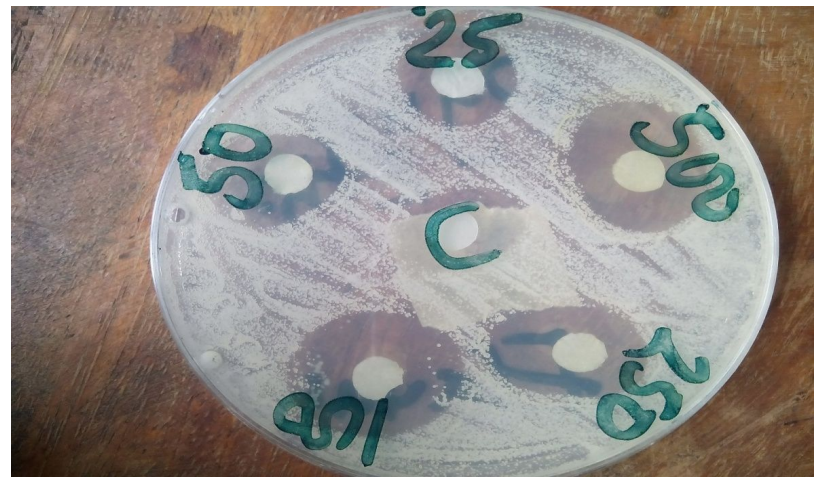

Fig. 3. Diameter zone of inhibition ( $\mathrm{mm}$ ) of the crude ethanol extracts of $V$. amygdalina against C. albicans

The believe of local people in the use of chewing stick (V. amygdalina) as cleansing and antimicrobial in nature proved productive; since both gram-negative and gram-positive bacteria and fungi were sensitive to the extracts. The highest zone of inhibition of $22.5 \mathrm{~mm}$ was observed at $500 \mathrm{mg} / \mathrm{ml}$ for ethanolic extract against $P$. aeruginosa, followed by zone of inhibition of $20.0 \mathrm{~mm}$ of ethyl acetate extract against $A$. niger and the least ZOI of $18.5 \mathrm{~mm}$ was observed in chloroform extract against $P$.

\section{REFERENCES}

Adekunle AA, Odukoya KA. Antifungal activities of ethanol and aqueous crude extracts of four Nigerian chewing sticks. Ethnobotanical Leaf- lets 2006;10:24-40.

Adelowo FE, Oladeji SO. Spectrophotometric analysis of phenolic compounds in Senna alata. Am. J. Adv. Sci. Res. 2016;3:246-53.

Agarwal A, Bora D, Agarwal C, Kumar R, Choudhary V. CNS stimulant and antidepressant activity of seeds of Abelmoschus esculentus in rats. Bull. Pharm. Res. 2015; 5(2):47-50.

Akinyemi KA. Antibacterial screening of five Nigerian medicinal plants against $S$. typhi and S. paratyphi. J. Nig. Inf. Cont. Assoc. 2000;3(1):30-3.

Al Sadhan RI, Almas K. Miswak (chewing stick): A cultural and scientific heritage. Saudi Dent. J. 1999;11(2):80-8.

Avula VV, Bora D, Upreti S, Jonathan SK, Rijal S. Effect of aqueous extract of Brassica olera-ceae var Italica (Broccoli) inflorescence in phenyl hydrazine induced anemic rats. Bull. Pharm. Res. 2015;5(3):81-3. aeruginosa and Klebsiella sp. The activity shown in ethanolic extract could be due to the polarity of the solvent. Ethanol has proved to be an important solvent in phytochemical extraction (extracts more active compound) (Ibekwe et al 2000). The ethanolic extract compared statistically with the standard antibiotics (Streptomycin and Gentamicin); the inhibition observed in Klebsiella sp, $E$. coli and $P$. aeruginosa were significantly higher than Streptomycin. The ethanolic extract showed significant activity against Trichoderma sp. when compared to Nystatin.

\section{CONCLUSION}

Extracts of the stem of $V$. amygdalina (chewing stick) proved effective in inhibiting both bacterial and fungal infections. The antimicrobial activity could be due to the presence of the phytochemicals such as flavonoids, saponins, tannins. The results suggested that the ethanol extract of the chewing stick showed higher inhibitory effects on most of the test organisms when compared with chloroform and ethyl acetate extracts, hence appraising ethanol as a better solvent for extraction.

Chopra RN, Nayar SL, Chopra IC. In Glossary of Indian Medicinal Plants, Council of Scientific and Industrial Research, New Delhi, 1956; 1:197.

Dahiya R. Total synthesis and biological potential of psammosilenin A. Arch. Pharm. (Weinheim) 2008;341(8): 502-9. [DOI: 10.1002/ardp.200800006]

Dahiya R. Synthesis of a phenylalanine-rich peptide as potential anthelmintic and cytotoxic agent. Acta Pol. Pharm. 2007;64(6): 509-16.

Dahiya R, Kumar A. Synthetic and biological studies on a cyclopolypeptide of plant origin. J. Zhejiang Univ. Sci. B 2008;9(5):391-400. [DOI: 10.1631/jzus.B0720001]

Gajendiran A, Thangaraman V, Thangamani S, Ravi D, Abraham J. Antimicrobial, antioxidant and anticancer screening of Ocimum basilicum seeds. Bull. Pharm. Res. 2016;6(3):114-9. [DOI: 10.21276/bpr.2016.6.3.5]

Ibekwe VI, Ubochi KC, Anyanwu BN. Prevalence of penicillin resistance in organisms that cause sexually transmitted diseases in Port Harcourt, Nigeria. Int. J. Environ. Health 
Res. 2000;10(3):251-5.

Karthishwaran K, Mirunalini S, Dhamodharan G, Krishnaveni M, Arulmozhi V. Phytochemical Investigation of methanolic extract of the leaves of Pergularia daemia. J. Biol. Sci. 2010; 10(3):242-6. [DOI: 10.3923/jbs.2010.24 2.246]

Ndukwe K, Okeke IN, Lamikanra A, Adesina SK, Aboderin 0. Antibacterial activity of aqueous extracts of selected chewing sticks. J. Contem. Dent. Pract. 2005;6(3):1-8.

Onwuliri FC. Antimicrobial studies of the extracts of Acalypha wllkesiana L. on microorganisms associated with wound and skin infections. West Afr. J. Biol. Sci. 2004; 15:15-19.

Owoyale JA, Olatunji GA, Oguntoye SO. Antifungal and antibacterial activities of an alcoholic extract of Senna alata leaves. J. Appl. Sci. Environ. Mgt. 2005;9(3):105-7.
Shrestha DK, Sapkota H, Baidya P, Basnet S. Antioxidant and antibacterial activities of Allium sativum and Allium cepa. Bull. Pharm. Res. 2016;6(2):50-5. [DOI: 10.21 276/bpr.2016. 6.2.3]

Srividya AR, Dhanabal SP, Yadav AK, Sathish Kumar MN, Vishnuvarthan VJ. Phytopreventive anti-hyperlipidemic activity of Curcuma zedoaria. Bull. Pharm. Res. 2012; 2(1):22-5.

Sule WF, Okonko IO, Joseph TA, Ojezele MO, Nwanze JC, Alli JA, Adewale OG. In vitro antifungal activity of Senna alata Linn. crude leaf extract. Res. J. Biol. Sci. 2010;5(3):275-84.

Vieira RF, Skorupa LA. Brazilian medicinal plants gene bank. Acta Horticul. 1993;330:51-58. [DOI: 10.17660/ ActaHortic.1993.330.4]

https://www.prota4u.org/database/protav8.asp?g=pe\&p= Vernonia+amygdalina+Delile 